\title{
FACTORS AFFECTING THE USAGE OF ONLINE COURSE DELIVERY TOOLS
}

\author{
Joseph Packy Laverty, Robert Morris University, laverty@rmu.edu \\ David F. Wood, Robert Morris University, wood@rmu.edu \\ Darcy Tannehill, Robert Morris University, tannehill@rmu.edu \\ Frederick G. Kohun, Robert Morris University, kohun@rmu.edu \\ John Turchek, Robert Morris University, turchek @rmu.edu
}

\begin{abstract}
The impact of online education continues to grow in terms of enrolled students, disciplines, and inclusion of higher education institutions. The quality and effectiveness of online courses varies considerably. Instructional designers frequently lack content expertise and many faculty may not take advantage of the online tools found in modern learning management systems. A previous study reported that most online faculty did not use or value many online course tools. This study considers the effects of online faculty background in technology and academic discipline with the use of online course tools. Recommendations to improve online course design are provided.
\end{abstract}

Keywords: Online Course Delivery, Learning Management Systems, Online Course Tools, Instruction Technologies, Word Processing, PowerPoint

\section{INTRODUCTION}

The impact of online education continues to grow in terms of enrolled students, disciplines, and inclusion of higher education institutions. Since University of Phoenix started its online programs in 1989, even the most elite universities have joined the online education game [3, 5]. In May of 2012 Harvard and the Massachusetts Institute of Technology (M.I.T.) formed a non-profit partnership, named as edX, to provide $\$ 16$ million to finance free online courses. Harvard and M.I.T. joined other elite universities such as Stanford, University of Pennsylvania, and the University of Michigan to provide free, non-credit, self-paced online courses [8].

From an institutional or macro point of view, the benefits of online education include new revenue flows, serving non-traditional populations, improving retention, responding to space constraints, managing costs, improving faculty productivity, and improved learning outcomes. Online education also faces many obstacles, which include student and faculty preference for traditional instruction, high initial development cost, course scheduling, instructor coordination, faculty lack of ownership, customization, union and faculty promotion/tenure rules, and accreditation concerns [2].

Research into the growing importance of online education for colleges and universities continues. However, the actual design of an online course is frequently guided by an instructional designer who does not have requisite content knowledge, while online faculty may have limited online course design expertise. The quality and effectiveness of online courses varies considerably. Laverty recommended one-on-one collaboration between the faculty member and the instructional designer may be effective more than large-group faculty instructional training [7].

It is common to require online instruction design training before faculty are permitted to teach an online course. Some training either assumes that faculty has the necessary technological background or simplifies the online course design. Lacking content expertise, the online instructional design trainer may not emphasize the appropriate online tools for the discipline. A popular approach to blend online delivery with advanced content is to record instructor lectures and provide access in an asynchronous mode, it may ignore the benefits of online assessment, collaboration, virtual classrooms, adaptive course management and other online tools more appropriate to the content and discipline.

Laverty reported that most faculty teaching online courses did not use or value many online course tools [7]. The current study considers the effects of online faculty background in technology and academic discipline with the use 


\section{Issues in Information Systems}

Volume 13, Issue 2, pp. 41-50, 2012

of online course tools. Faculty differ widely in their acceptance and expertise in many general instructional technologies such as word processing, PowerPoint presentations, use of graphic and images editing, and use of audio and video technologies. Without an appropriate background in technology, faculty teaching online courses may not have the prerequisite skills necessary to develop effective courses. Effective design and development of online courses may also be influenced by the course content associated with a specific academic discipline. Online instructional designers and faculty may not have the expertise to apply effective online course tools to some disciplines.

\section{BACKGROUND AND METHODOLOGY}

During the last decade the use of online learning management systems has increased in terms of academic instructional delivery, diversity of disciplines, education levels, technology, availability of online teaching and course management tools. Laverty conducted a study into the faculty use and perceived value of online tools used in most learning management systems. The results of the analysis indicated that 1) $30 \%$ of faculty did not use online instruction systems, 2) the majority of online faculty rarely or never used many online tools, 3) a majority of the online faculty perceived little value of many online tools, and 4) less than $21 \%$ of the faculty users rated themselves as advanced online course developers. The results also indicated that 1) senior faculty were less likely to be involved in online course delivery, 2) the same concerns of online delivery were common across disciplines, 3) the business, mathematics, English, engineering and science disciplines least used online course delivery, and 4) education used online course delivery [7]. Descriptive statistics were reported, but tests of significance were not conducted

Table 1 lists the least used online content, assessment and course administration tools as reported in "Improving the LMS Selection Process: Instructor Concerns, Usage and Perceived Value of Online Course Delivery Tools"[7]. While faculty may deliver or develop online courses, this does not mean that faculty have appropriately applied or taken advantage of available online course tools. As learning management systems add new innovative online tools, one must ask why some instructional designers and online faculty do not take advantage of existing online course tools.

\begin{tabular}{|c|c|c|}
\hline \multicolumn{2}{|c|}{ Table 1 } \\
\hline Instructional Content Tools & Online Assessment Tools & Online Course Management Tools \\
\hline $\begin{array}{c}\text { Import course content, quizzes, tests, } \\
\text { other courses, etc. }\end{array}$ & Blogs or wikis & $\begin{array}{c}\text { Student assessment passwords or other } \\
\text { enhanced online assessment security }\end{array}$ \\
\hline $\begin{array}{c}\text { Use of graphics, images, audio or video } \\
\text { developed by the instructor }\end{array}$ & Virtual classroom, & Online class dashboards \\
\hline $\begin{array}{c}\text { Use of PowerPoint presentations } \\
\text { developed by others }\end{array}$ & Student journals & HTML editing \\
\hline $\begin{array}{c}\text { Use of graphics, etc., developed by } \\
\text { others. }\end{array}$ & Online groups & Performance reports \\
\hline & Anti-plagiarism tools, e.g., Turnitin & Adaptive release of course content \\
\hline
\end{tabular}

This study investigates the following research questions concerning faculty's use of various online course tools.

1) Is the general technological background of online faculty associated with the use of online course tools?

2) Are differences in faculty disciplines associated with their use of online course tools?

An online survey was administered to adjunct, part-time, and full-time faculty. Response data was captured and stored using Vovici. Respondents were categorized as either using learning management systems (Users) or not using (Non-Users) learning management systems. 81 out of 116 faculty respondents reported using learning management systems. Each online faculty respondent had experience using the Blackboard learning management system. 


\section{Issues in Information Systems}

Volume 13, Issue 2, pp. 41-50, 2012

Data concerning the technology background of the respondent were collected. Word processing, PowerPoint presentations, use of graphics and images, and use of audio or video technologies were studied. Concerning their use of instructional technology, respondents were asked to report their level of use by selecting one or more options: 1) no use, 2) use the technology content provided by others, 3) modify technology content provided by others, 4) basic development of technology content, and 5) advanced development of technology content.

Research into faculty use of instructional technology has been popular. Guidry \& Lorenz studied the level of faculty use of instructional technologies across academic disciplines. The instructional technologies reviewed were content management systems, clickers, e-Portfolios, blogs, collaborative editing tools, video, games, surveys, video or voice conferencing, and anti- plagiarism tools. Their study found that faculty use of blogs, collaborative editing tools, and games and simulations was low across all disciplines. Content management systems were the most popular use of technology. By discipline, Education faculty accounted for greatest use of instructional technology, and Professional and Business faculty used instructional technologies the least [4]. Faculty respondents selected one academic discipline category. Academic disciplines studied included Business, Computer or Information Systems, English or Communication Skills, Education, Social Sciences, Mathematics or Science/Engineering, and Nursing. Traditional instruction design frequently differs among academic disciplines in terms of content, assessment, structure, collaboration, feedback, degree of difficulty and many other constructs. Laverty presented descriptive data that suggested that academic discipline may also be a factor which affects how online faculty use online course tools [7].

In this study online faculty reported their use of 36 specific online tools grouped into three categories, i.e., instructional content tools, assessment, and course management. A five-point ratio scale was used to measure the consistency of use in their online courses between "Never Used" to "Used 100\% of the Time."

Data was analyzed using "R". "R" is an open-source statistical and graphing programming language [6]. Descriptive statistics and the logistic regression model were used to analyze the data. Logistic regression is a class of statistical linear models which can be used to test and predict a discrete or continuous outcome based on one or more dichotomous, discrete or continuous independent variables. The logistic regression makes no assumption about the distribution of the independent variables. A Wald test was used to test the statistical significance of each coefficient in the model. A Wald test calculates a Z statistic, which is compared to a normal distribution. The sum of these statistics squared can test the entire model using the Chi Square distribution [1].

\section{ANALYSIS AND FINDINGS}

\section{Technology Background of Online Faculty}

Descriptive statistics measuring the faculty's $(n=116)$ use of general instructional technologies, independent of their use of online courses, are presented in Tables 2, 3, 4 and 5. Table 2 compares word processing skills between online and non-online faculty. $60 \%$ of online faculty as compared to $48 \%$ of non-online faculty classified themselves as an advanced user of word processing technologies. $40 \%$ of online faculty as compared to $71 \%$ of non-online faculty classified themselves as a basic user of word processing technologies.

\begin{tabular}{|l|c|c|c|c|c|}
\hline \multicolumn{8}{|c|}{ Taculty Instructional of Word Processing Documents and Skills in Using Word Processors } \\
by Users and Non-Users of LMS Systems (n=116)
\end{tabular}

Table 3 compares the use of PowerPoint presentations between faculty who used or developed online courses and those who did not. As compared to online faculty, non-online faculty were less likely to use PowerPoint 


\section{Issues in Information Systems}

Volume 13, Issue 2, pp. 41-50, 2012

presentations, i.e., $8 \%$ as compared to $37 \%$. On the other hand, fewer online faculty reported advanced use of PowerPoint presentations compared to word processing, i.e., $60 \%$ as compared to $43 \%$.

\begin{tabular}{|c|c|c|c|c|c|}
\hline \multicolumn{6}{|c|}{$\begin{array}{c}\text { Table } 3 \\
\begin{array}{c}\text { Faculty Instructional Use of PowerPoint Presentations And Skills in PowerPoint Development } \\
\text { by Users and Non-Users of LMS Systems } \\
(n=116)\end{array}\end{array}$} \\
\hline $\begin{array}{c}\text { Use of Learning } \\
\text { Management Systems }\end{array}$ & $\begin{array}{l}\text { Do not use } \\
\text { PowerPoint } \\
\text { Presentation } \\
\text { Software } \\
\end{array}$ & $\begin{array}{l}\text { Use PowerPoint } \\
\text { Presentations } \\
\text { provided by } \\
\text { Others }\end{array}$ & $\begin{array}{l}\text { Modify Existing } \\
\text { PowerPoint } \\
\text { Presentation } \\
\text { provided by others }\end{array}$ & $\begin{array}{l}\text { Basic Use of } \\
\text { PowerPoint } \\
\text { Presentation } \\
\text { Software } \\
\end{array}$ & $\begin{array}{l}\text { Advanced Use of } \\
\text { PowerPoint } \\
\text { Presentation Software }\end{array}$ \\
\hline Users (n=81) & $7 / 8.6 \%$ & $8 / 9.8 \%$ & $12 / 14.8 \%$ & $35 / 43.2 \%$ & $35 / 43.2 \%$ \\
\hline Non-users (n=35) & $13 / 37.1 \%$ & $4 / 11.4 \%$ & $2 / 9.7 \%$ & $9 / 25.7 \%$ & $7 / 20.0 \%$ \\
\hline$(n=116)$ & $20 / 17.2$ & $12 / 10.3 \%$ & $14 / 12.0 \%$ & $44 / 37.9 \%$ & $42 / 36.2 \%$ \\
\hline
\end{tabular}

Table 4 compares the use of graphics and images between faculty who used or developed online courses and those who did not. As compared to online faculty, non-online faculty were less likely to use images or graphics, i.e., 54\% as compared to $32 \%$. As compared to online faculty, non-online faculty were also less likely to have basic or advanced graphic editing or development skills. Overall, both online faculty and non-online faculty used fewer images or graphics and skills as compared to PowerPoint presentations or word processing.

\begin{tabular}{|c|c|c|c|c|c|}
\hline \multicolumn{6}{|c|}{$\begin{array}{c}\text { Table } 4 \\
\text { Faculty Instructional Use of Graphics and Skills in Graphic Development } \\
\text { by Users and Non-Users of LMS Systems }(n=116)\end{array}$} \\
\hline $\begin{array}{c}\text { Use of Learning } \\
\text { Management Systems }\end{array}$ & $\begin{array}{l}\text { Do not use Graphical } \\
\text { Development } \\
\text { Software }\end{array}$ & $\begin{array}{l}\text { Use Graphics } \\
\text { provided by } \\
\text { Others }\end{array}$ & $\begin{array}{l}\text { Modify Existing } \\
\text { Graphics } \\
\text { provided by } \\
\text { others }\end{array}$ & $\begin{array}{l}\text { Basic Use of } \\
\text { Graphic } \\
\text { Development } \\
\text { Software }\end{array}$ & $\begin{array}{l}\text { Advanced Use of Graphic } \\
\text { Development Software }\end{array}$ \\
\hline $\begin{array}{l}\text { Use Learning } \\
\text { Management Systems } \\
(\mathrm{n}=81)\end{array}$ & $26 / 32.0 \%$ & $18 / 22.2 \%$ & $8 / 9.8 \%$ & $19 / 23.4 \%$ & $16 / 19.7 \%$ \\
\hline $\begin{array}{l}\text { Do not Use Learning } \\
\text { Management Systems } \\
(\mathrm{n}=35)\end{array}$ & $19 / 54.2 \%$ & $7 / 20.0 \%$ & $4 / 11.4 \%$ & $0 / 0.0 \%$ & $5 / 14.2 \%$ \\
\hline$(\mathrm{n}=116)$ & $45 / 38.7 \%$ & $25 / 21.5 \%$ & $12 / 10.3 \%$ & $19 / 16.3 \%$ & $21 / 8.1 \%$ \\
\hline
\end{tabular}

Table 5 compares the use of audio and videos between faculty who use or developed online courses and those who did not. The use and development skills of audio and video were less for both online faculty and non-online faculty as compared to other reviewed instructional technologies. As compared to online faculty, non-online faculty were less likely to have basic or advanced audio or video development skills. On the other hand, non-online faculty were slightly more likely to use audio or videos as an instructional technology i.e. 54\% as compared to $49 \%$.

\begin{tabular}{|c|c|c|c|c|c|}
\hline \multicolumn{6}{|c|}{$\begin{array}{l}\text { Table } 5 \\
\begin{array}{c}\text { Faculty Instructional Use of Audio or Videos and Skills in Audio-Video Development } \\
\text { by Users and Non-Users of LMS Systems } \\
(n=116)\end{array}\end{array}$} \\
\hline & $\begin{array}{l}\text { Do not use } \\
\text { Audio/Video } \\
\text { Editing Software }\end{array}$ & $\begin{array}{l}\text { Use Audio or } \\
\text { Videos } \\
\text { provided by } \\
\text { Others }\end{array}$ & $\begin{array}{l}\text { Modify Existing } \\
\text { Audio or Video } \\
\text { provided by } \\
\text { others }\end{array}$ & $\begin{array}{l}\text { Basic Use of } \\
\text { Audio or Video } \\
\text { Editing Software }\end{array}$ & $\begin{array}{l}\text { Advanced Use of Audio } \\
\text { or Video Editing } \\
\text { Software }\end{array}$ \\
\hline $\begin{array}{l}\text { Use learning management } \\
\text { systems }(n=81)\end{array}$ & $19 / 23.4 \%$ & $32 / 39.5 \%$ & $8 / 9.8 \%$ & $21 / 25.9 \%$ & $10 / 12.3 \%$ \\
\hline $\begin{array}{l}\text { Do not Use learning } \\
\text { management systems } \\
(\mathrm{n}=35)\end{array}$ & $6 / 17.1 \%$ & $19 / 54.2 \%$ & $1 / 1.8 \%$ & $4 / 11.4 \%$ & $1 / 3.8 \%$ \\
\hline$(n=116)$ & $26 / 21.5 \%$ & $51 / 43.9 \%$ & $9 / 7.7 \%$ & $25 / 21.5 \%$ & $11 / 9.4 \%$ \\
\hline
\end{tabular}




\section{Issues in Information Systems}

Volume 13, Issue 2, pp. 41-50, 2012

\section{Relationship Between Online Faculty Technology Background and Use of Online Course Tools}

For those faculty who use online instruction $(\mathrm{n}=81$ ), a proportional odds ordinal logistic regression model was used to determine the significance of the relationship between technology background of the faculty and the use of online course tools. Four independent variables were used to represent the use of instructional technologies, i.e., word processing, PowerPoint presentations, graphics, and audio-video. Results of the analysis are presented in Tables 6, 7, and 8 for three categories of learning management tools, i.e., online instructional content, assessment and course management. Each row of the table represented a specific online course tool common to most learning management systems. The analysis was limited to faculty members who had used online courses $(n=81)$.

Column 1 presents the Chi-square of the Likelihood Ratio test of the four-factor logistic regression model for each online instructional tool. Online instruction tools which had a logistic model probability (level of significance) less than .1000 were considered significant and are identified by an asterisk. When significant a modified coefficient of determination ( $\mathrm{r} 2)$ was also presented.

Column 5 lists the mean value measuring the use for each online course tool. This descriptive statistic may provide supplementary information to interpret the lack of significance between an online course tool and technology background. A mean value of 4.0 indicated that every faculty member always used the specified online course tool $100 \%$ of the time in their course designs A mean value of zero indicated that no faculty member used the specified online course tool in their course designs. For example, if all online faculty always used a online course tool, there would be no technology effect. There is no variance with a mean of zero of four.

\begin{tabular}{|c|c|c|c|c|c|}
\hline \multicolumn{6}{|c|}{$\begin{array}{c}\text { Relationship Between Instructor Technology Background and Online Content Tools } \\
\text { Table } 6\end{array}$} \\
\hline Online Instruction Content Tools & $\begin{array}{c}\text { Model } \\
\text { Level of Significance } \\
\text { and R2 } \\
{[1]}\end{array}$ & $\begin{array}{c}\text { Specific } \\
\text { Technology } \\
{[2]}\end{array}$ & $\begin{array}{c}\text { Level of } \\
\text { Significance } \\
{[3]}\end{array}$ & $\begin{array}{c}\text { Effect } \\
\text { Odds } \\
\text { Ratio } \\
{[4]}\end{array}$ & $\begin{array}{c}\text { Mean } \\
\text { Use } \\
{[5]}\end{array}$ \\
\hline $\begin{array}{l}\text { Use of online course syllabus, course objectives, rules, } \\
\text { and other course administration information. }\end{array}$ & 0.7940 & & & & 3.52 \\
\hline $\begin{array}{l}\text { Use of Online course calendar or schedule of } \\
\text { assignments, projects, quizzes, tests and other } \\
\text { schedule information. }\end{array}$ & 0.9405 & & & & 2.78 \\
\hline $\begin{array}{l}\text { Downloads of assignments, projects, and other } \\
\text { instructional documents, workbooks or databases. }\end{array}$ & 0.1842 & & & & 3.00 \\
\hline Use PowerPoint presentations developed by others. & 0.1449 & & & & 1.71 \\
\hline Instructor development of PowerPoint presentations & $\begin{array}{l}0.0001^{*} \\
\mathrm{r} 2=.288\end{array}$ & PPT & 0.0003 & 4.29 & 2.36 \\
\hline $\begin{array}{l}\text { Use of images, graphic, images, audio or video } \\
\text { developed by others. }\end{array}$ & $\begin{array}{l}0.0009^{*} \\
\mathrm{r} 2=.230\end{array}$ & $\begin{array}{l}\text { WP } \\
\text { PPT }\end{array}$ & $\begin{array}{l}0.0539 \\
0.0171\end{array}$ & $\begin{array}{l}0.46 \\
2.39\end{array}$ & 1.82 \\
\hline $\begin{array}{l}\text { Instructor development of images, graphics, audio or } \\
\text { video. }\end{array}$ & $\begin{array}{c}0.0001^{*} \\
\mathrm{r} 2=.3000\end{array}$ & $\begin{array}{l}\text { GRP } \\
\text { AV }\end{array}$ & $\begin{array}{l}0.0140 \\
0.0812\end{array}$ & $\begin{array}{l}3.10 \\
2.14\end{array}$ & 1.36 \\
\hline $\begin{array}{l}\text { Import course content, quizzes, tests, packages or } \\
\text { cartridges from publishers or other courses. }\end{array}$ & 0.2709 & & & & 1.21 \\
\hline $\begin{array}{l}\text { Use of external URL links to content to support } \\
\text { course content. }\end{array}$ & $\begin{array}{l}0.0026^{*} \\
\mathrm{r} 2=.205\end{array}$ & PPT & 0.0152 & 2.27 & 2.64 \\
\hline $\begin{array}{l}\text { Import course content, quizzes, tests, packages or } \\
\text { cartridges from publishers or other sources }\end{array}$ & $0.1819 *$ & WP & .0226 & .42 & 2.34 \\
\hline
\end{tabular}




\section{Issues in Information Systems}

Volume 13, Issue 2, pp. 41-50, 2012

\begin{tabular}{|c|c|c|c|c|c|}
\hline \multicolumn{6}{|c|}{$\begin{array}{c}\text { Relationship Between Instructor Technology Background and Online Course Assessment Tools } \\
\text { Table } 7\end{array}$} \\
\hline Online Assessment Tools & $\begin{array}{c}\text { Model } \\
\text { Level of } \\
\text { Significance } \\
\text { and R2 } \\
{[1]}\end{array}$ & $\begin{array}{c}\text { Specific } \\
\text { Technology } \\
{[2]}\end{array}$ & $\begin{array}{c}\text { Level of } \\
\text { Significance } \\
{[3]}\end{array}$ & $\begin{array}{c}\text { Effect } \\
\text { Odds } \\
\text { Ratio } \\
\text { [4] }\end{array}$ & $\begin{array}{c}\text { Mean } \\
\text { Use } \\
{[5]}\end{array}$ \\
\hline Use of online quizzes or tests. & .8855 & & & & 1.94 \\
\hline Use of online assignment submission. & .3202 & & & & 2.61 \\
\hline Use of Turnitin or other anti-plagiarism tools. & .6448 & & & & 1.26 \\
\hline Use of online grade book and online grading. & .5433 & & & & 2.82 \\
\hline Use of online groups. & .4270 & & & & 1.09 \\
\hline Use of online student journals. & .5109 & & & & .88 \\
\hline Use of online collaboration. & $\begin{array}{c}.0529 * \\
\mathrm{r} 2=.124\end{array}$ & None & & & 1.32 \\
\hline Use of online discussion boards. & .7559 & & & & 2.34 \\
\hline Use of a wiki. & $\begin{array}{r}.0052^{*} \\
\mathrm{r} 2=.215\end{array}$ & None & & & .43 \\
\hline Use of a blog. & .1908 & & & & .36 \\
\hline Use of a real time virtual classroom. & $\begin{array}{c}.0507 * \\
\mathrm{r} 2=.140\end{array}$ & $\mathrm{AV}$ & $.0314 *$ & 3.21 & .42 \\
\hline Use of recorded instructor lectures (videos). & $\begin{array}{l}.0001 * \\
\mathrm{r} 2=.303\end{array}$ & $\mathrm{AV}$ & $.0126^{*}$ & 3.44 & .62 \\
\hline
\end{tabular}

When a Logistic Regression Model Chi Square probability was significant, a further review was conducted to determine which instruction technologies had a significant effect. Column 2 presented a notation using WP (word processing), PPT (PowerPoint Presentations), GRP (graphic technologies), or AV (audio, visual technologies) when the Column 3 level of significance was less than .1000.

The "None" was reported when the logistic regression model was significant, but no specific technology background could be identified as significant or important to the use of a specific online tool. A significance of technology was found, but the variance between technologies was not significant to identify a more important technology.

Column 4 presents the Effect Odds Ratio for each online instruction tool. The Effect Odds Ratio provides a practical interpretation of the degree of significance. Consider the reported value of 4.29 for the Effect Odds Ratio concerning the use of Faculty Development PowerPoint Presentation. This value would indicate that for each level of technology use, the odds of using a specific online tool would be multiplied by 4.29. On the other hand, the Effect Odds Ratio of 2.27 would indicate that for each level PowerPoint background, the use of external links (URLs) in an online course would be more likely. Higher Effect Odds Ratios not only indicate a greater likely of use, but also suggest the greater importance of basic and advanced skills of the technology.

Table 8 presents an analysis of the technology background of online faculty and the use of online course management tools. These results were more interesting. These differences may affect the design, organization, and management of an online course. While the appropriate management, organization and instructional design of an online course are related to many factors, of Table 8 indicates that the faculty's expertise in several general instructional technologies is most likely one of those factors. 


\section{Issues in Information Systems}

Volume 13, Issue 2, pp. 41-50, 2012

\begin{tabular}{|c|c|c|c|c|c|}
\hline \multicolumn{6}{|c|}{$\begin{array}{c}\text { Relationship Between Instructor Technology Background and Online Course Management Tools } \\
\text { Table } 8\end{array}$} \\
\hline Online Course Management Tools & $\begin{array}{c}\text { Model } \\
\text { Level of } \\
\text { Significance } \\
\text { and R2 } \\
{[1]} \\
\end{array}$ & $\begin{array}{c}\text { Specific } \\
\text { Technology } \\
{[2]}\end{array}$ & $\begin{array}{c}\text { Level of } \\
\text { Significance } \\
{[3]}\end{array}$ & $\begin{array}{c}\text { Effect } \\
\text { Odds } \\
\text { Ratio } \\
{[4]}\end{array}$ & $\begin{array}{c}\text { Mean } \\
\text { Use } \\
{[5]}\end{array}$ \\
\hline Organized course content by areas or folders. & $\begin{array}{c}.0004^{*} \\
\mathrm{r} 2=.257\end{array}$ & $\begin{array}{l}\text { WP } \\
\text { PPT }\end{array}$ & $\begin{array}{l}.0884 * \\
.0972 *\end{array}$ & $\begin{array}{l}1.98 \\
1.94\end{array}$ & 2.58 \\
\hline $\begin{array}{l}\text { Copied or moved course content or folders within a course } \\
\text { section. }\end{array}$ & $\begin{array}{l}.0022 * \\
\mathrm{r} 2=.213\end{array}$ & PPT & $.0039 *$ & 3.05 & 2.37 \\
\hline $\begin{array}{l}\text { Copied or moved course content or folders between course } \\
\text { sections. }\end{array}$ & $\begin{array}{l}.0932 * \\
\mathrm{r} 2=.107\end{array}$ & PPT & $.0676^{*}$ & 1.90 & 2.24 \\
\hline Use of online early warning systems. & .1575 & & & & .59 \\
\hline $\begin{array}{l}\text { Use of adaptive release for course content or assessment } \\
\text { tools. }\end{array}$ & $\begin{array}{l}.0298^{*} \\
\mathrm{r} 2=.144\end{array}$ & GRP & .0151 & 3.07 & 1.08 \\
\hline Use of online class performance reports. & $\begin{array}{l}.0679 * \\
\mathrm{r} 2=.121\end{array}$ & none & & & 1.26 \\
\hline Use of online class dashboards & .2922 & GRP & $.0871 *$ & 2.24 & .85 \\
\hline Edit, manage or customize online grade books & .6474 & & & & 2.63 \\
\hline Add, modified or delete students or groups & .4128 & & & & 2.68 \\
\hline $\begin{array}{l}\text { Export, import or archive course content or assessment } \\
\text { data. }\end{array}$ & $\begin{array}{c}.0950^{*} \\
\mathrm{r} 2=.108\end{array}$ & none & & & 2.27 \\
\hline $\begin{array}{l}\text { Create or edit online assessment questions or surveys using } \\
\text { text. }\end{array}$ & 0.3377 & & & & 1.61 \\
\hline Create or edit any online course content using HTML. & $\begin{array}{l}0.0003^{*} \\
\mathrm{r} 2=.275\end{array}$ & $\begin{array}{l}\text { WP } \\
\text { GRP } \\
\text { AV }\end{array}$ & $\begin{array}{l}0.0896 \\
0.0107 \\
0.0842\end{array}$ & $\begin{array}{l}0.43 \\
3.79 \\
2.23\end{array}$ & .97 \\
\hline Use randomized questions in an online assessment. & 0.1056 & & & & 1.35 \\
\hline $\begin{array}{l}\text { Use student assessment passwords or other enhanced online } \\
\text { assessment security. }\end{array}$ & $\begin{array}{l}0.0097 * \\
\mathrm{r} 2=.121\end{array}$ & WP & 0.0024 & 0.19 & .73 \\
\hline $\begin{array}{l}\text { Required on-ground assessment or student requirement for } \\
\text { an online course. }\end{array}$ & 0.4755 & & & & .67 \\
\hline
\end{tabular}

Faculty background in instructional technologies was significantly related to the use of 17 of 36 online tools studied. Faculty technological experience in word processing was a significant factor in four online tools. PowerPoint experience was significant in six online tools. Image and graphic experience were significant factors in four online tools and audio-video experiences were a significant factor in four online tools.

\section{Relationship Between the Academic Discipline and Online Course Tools}

A Logistic Multiple Regression Model was used to determine the significance of the relationship between academic discipline and the use of online course tools. Eight independent variables were used to represent the academic disciplines, i.e., Business, Computer or Information Systems, English or Communication Skills, Education, Social Sciences, Mathematics or Science/Engineering, and Nursing. Tables 9, 10, and 10 present findings in a format similar to the previous analysis of the technological background of faculty. A .1000 level of significance was used. For levels of significance less than .1000 in the logistic regression model, a further analysis was conducted to identify each significant discipline. A modified version of the coefficient of determination was also provided.

The values of independent variables, i.e., academic discipline, were dichotomous, e.g., yes and no. Interpretation of the Effect Odds Ratio needs to be clarified. Four significant disciplines were identified that affected the use of images, graphic, images, audio or video developed by others. The Effect Odds Ratio for Education was 2.60 should be interpreted that education faculty had 2.60 times the odds of use of this online tool. The Effect Odds Ratio of Math and Science was 23.77. This means that the odds that they would use the tools were multiplied by 23.77 as compared not to being in Math and Science. 


\section{Issues in Information Systems}

Volume 13, Issue 2, pp. 41-50, 2012

\begin{tabular}{|c|c|c|c|c|c|}
\hline \multicolumn{6}{|c|}{$\begin{array}{c}\text { Relationship Between Discipline and Use of Online Content Tools } \\
\text { Table } 9\end{array}$} \\
\hline Online Instruction Content Tools & $\begin{array}{c}\text { Model } \\
\text { Level of } \\
\text { Significance } \\
\text { and R2 } \\
{[1]} \\
\end{array}$ & $\begin{array}{c}\text { Specific } \\
\text { Discipline } \\
\text { [2] }\end{array}$ & $\begin{array}{c}\text { Level of } \\
\text { Significance } \\
{[3]}\end{array}$ & $\begin{array}{c}\text { Effect } \\
\text { Odds } \\
\text { Ratio } \\
{[4]}\end{array}$ & $\begin{array}{c}\text { Mean } \\
\text { Use } \\
{[5]}\end{array}$ \\
\hline $\begin{array}{l}\text { Use of online course syllabus, course objectives, rules, } \\
\text { and other course administration information. }\end{array}$ & $0 . .1387$ & & & & 3.52 \\
\hline $\begin{array}{l}\text { Use of online course calendar or schedule of } \\
\text { assignments, projects, quizzes, tests and other schedule } \\
\text { information. }\end{array}$ & $0 . .4450$ & & & & 2.78 \\
\hline $\begin{array}{l}\text { Downloads of assignments, projects, and other } \\
\text { instructional documents, workbooks or databases. }\end{array}$ & 0.4456 & & & & 3.00 \\
\hline Use of PowerPoint Presentations developed by others. & $\begin{array}{l}0 . .0086 * / \\
\mathrm{r} 2=0.266\end{array}$ & SOCSCI & 0.0937 & -2.42 & 1.71 \\
\hline $\begin{array}{l}\text { Use of PowerPoint Presentations modified or developed } \\
\text { by the instructor. }\end{array}$ & $\begin{array}{l}0.0101 * / \\
\mathrm{r} 2=0.257\end{array}$ & MED & 0.0645 & 14.90 & 2.36 \\
\hline $\begin{array}{l}\text { Use of images, graphic, images, audio or video } \\
\text { developed by others. }\end{array}$ & $\begin{array}{l}0.0313 * / \\
\mathrm{r} 2=0.220\end{array}$ & $\begin{array}{c}\text { COMP/IS } \\
\text { EDUC } \\
\text { COMM } \\
\text { MATH/SCI } \\
\end{array}$ & $\begin{array}{l}0.0447 \\
0.0520 \\
0.0640 \\
0.0357 \\
\end{array}$ & $\begin{array}{c}2.38 \\
2.60 \\
10.79 \\
23.77 \\
\end{array}$ & 1.82 \\
\hline $\begin{array}{l}\text { Use of images, graphic, images, audio or video } \\
\text { modified or developed by the instructor. }\end{array}$ & 0.4500 & & & & 1.36 \\
\hline $\begin{array}{l}\text { Import course content, quizzes, tests, packages or } \\
\text { cartridges from publishers or other courses. }\end{array}$ & 0.3473 & & & & 1.21 \\
\hline Use of URL or other links to content to support course. & 0.1892 & & & & 2.64 \\
\hline $\begin{array}{l}\text { Import course content, quizzes, tests, packages or } \\
\text { cartridges from publishers or other courses. }\end{array}$ & 0.6657 & & & & 2.34 \\
\hline
\end{tabular}

\begin{tabular}{|c|c|c|c|c|c|}
\hline \multicolumn{6}{|c|}{$\begin{array}{c}\text { Relationship Between Discipline and Use of Online Course Assessment Tools } \\
\text { Table } 10\end{array}$} \\
\hline Online Assessment Tools & $\begin{array}{c}\text { Model } \\
\text { Level of } \\
\text { Significance and } \\
\text { R2 } \\
{[1]} \\
\end{array}$ & $\begin{array}{c}\text { Specific } \\
\text { Discipline } \\
\text { [2] }\end{array}$ & $\begin{array}{c}\text { Level of } \\
\text { Significance } \\
{[3]}\end{array}$ & $\begin{array}{c}\text { Effect } \\
\text { Odds } \\
\text { Ratio } \\
\text { [4] }\end{array}$ & $\begin{array}{c}\text { Mean } \\
\text { Use } \\
{[5]}\end{array}$ \\
\hline Use of online quizzes or tests. & $\begin{array}{c}.0800 * / \\
\mathrm{r} 2=0.188\end{array}$ & None & & & 1.94 \\
\hline Use of online assignment submission. & $\begin{array}{c}.0039 * / \\
\mathrm{r} 2=0.288\end{array}$ & None & & & 2.61 \\
\hline Use of Turnitin or other anti-plagiarism tools. & 0.1340 & & & & 1.26 \\
\hline Use of online grade book and online grading. & 0.2256 & & & & 2.82 \\
\hline Use of online groups. & $0 . .0097^{*}$ & BUS & 0.0458 & -2.25 & 1.09 \\
\hline Use of online student journals. & $0.0154 *$ & SOCSCI & 0.0926 & -2.07 & .88 \\
\hline Use of online collaboration. PctUseOnlineCollab & $0.0006^{*}$ & $\begin{array}{c}\text { BUS } \\
\text { SOCSCI }\end{array}$ & $\begin{array}{l}0.0674 \\
0.0199\end{array}$ & $\begin{array}{c}0.07 \\
-3.98\end{array}$ & 1.32 \\
\hline Use of online discussion boards. & $0.0723 *$ & None & & & 2.34 \\
\hline Use of a wiki. & 0.1024 & & & & .43 \\
\hline Use of a blog. & 0.4594 & & & & .36 \\
\hline Use of a real time virtual classroom. & 0.1267 & & & & .42 \\
\hline Use of recorded instructor lectures (9videos). & 0.2939 & & & & .62 \\
\hline
\end{tabular}

The Effect Odds Ratio may be a positive or negative value. The Effect Odds Ratio for Social Science and the use of PowerPoint presentations developed by others was -2.42 . The analysis indicated that Social Science faculty were less likely to use PowerPoint Presentations provided by others than other faculty. However, one cannot assume that these faculty members developed their own presentations. 


\section{Issues in Information Systems}

Volume 13, Issue 2, pp. 41-50, 2012

\begin{tabular}{|c|c|c|c|c|c|}
\hline \multicolumn{6}{|c|}{$\begin{array}{c}\text { Relationship Between Academic Discipline and Online Course Management Tools } \\
\text { Table } 11\end{array}$} \\
\hline Online Course Management Tools & $\begin{array}{c}\text { Model } \\
\text { Level of } \\
\text { Significance } \\
\text { and R2 } \\
{[1]}\end{array}$ & $\begin{array}{c}\text { Specific } \\
\text { Technology } \\
{[2]}\end{array}$ & $\begin{array}{c}\text { Level of } \\
\text { Significance } \\
{[3]}\end{array}$ & $\begin{array}{c}\text { Effect } \\
\text { Odds } \\
\text { Ratio } \\
{[4]}\end{array}$ & $\begin{array}{l}\text { Mean } \\
\text { Use } \\
{[5]}\end{array}$ \\
\hline Organized course content by areas or folders. & 0.688 & & & & 2.58 \\
\hline $\begin{array}{l}\text { Copied or moved course content or folders within a course } \\
\text { section. }\end{array}$ & 0.7289 & & & & 2.37 \\
\hline $\begin{array}{l}\text { Copied or moved course content or folders between course } \\
\text { sections. }\end{array}$ & 0.1146 & & & & 2.24 \\
\hline Use of online early warning systems. & 0.1879 & & & & .59 \\
\hline $\begin{array}{l}\text { Use of adaptive release for course content or assessment } \\
\text { tools. }\end{array}$ & 0.5557 & & & & 1.08 \\
\hline Use of online class performance reports. & 0.4460 & & & & 1.26 \\
\hline Use of online class dashboards & $0.0278^{*}$ & None & & & .85 \\
\hline Edit, manage or customize online grade books & 0.3211 & & & & 2.63 \\
\hline Add, modified or delete students or groups & 0.3413 & & & & 2.68 \\
\hline $\begin{array}{l}\text { Export, import or archive course content or assessment } \\
\text { data. }\end{array}$ & 0.2461 & & & & 2.27 \\
\hline $\begin{array}{l}\text { Create or edit online assessment questions or surveys using } \\
\text { text. }\end{array}$ & 0.1293 & & & & 1.61 \\
\hline Create or edit any online course content using HTML. & $0.0804 *$ & None & & & .97 \\
\hline Use randomized questions in an online assessment. & 0.2294 & & & & 1.35 \\
\hline $\begin{array}{l}\text { Use student assessment passwords or other enhanced online } \\
\text { assessment security. }\end{array}$ & 0.1711 & & & & .73 \\
\hline $\begin{array}{l}\text { Required on-ground assessment or student requirement for } \\
\text { an online course. }\end{array}$ & $0.0543^{*}$ & None & & & .67 \\
\hline
\end{tabular}

Academic discipline was significantly related to the use of 12 of 36 online tools studied. However, the identity of specific disciplines could only be determined for the use of six of the twelve online course tools. When the identity could be determined several disciplines reported a negative Effect Odds Ratio. This means that these disciplines were less likely to use a tool. Business and Social Science were less likely to specific online tools in four instances. Nursing and Math and Science faculty reported the most likely in the use of faculty developed PowerPoint presentations and use of images and graphics of others, respectively.

\section{CONCLUSIONS AND RECOMMENDATIONS}

This study confirms that if faculty did not have the appropriate training in an instructional technology, they were less likely to use the online tool that corresponded to that technology. For example, instructors who had little skills in PowerPoint development did not frequently customize or develop PowerPoint presentations in online instruction. This result was expected.

The technology background regression model was significant for 17 out of the 36 online course tools studied. Overall, the technological background of the faculty teaching courses is an important factor in determining how faculty develop their online courses. Many courses have prerequisites. What should be the prerequisites for teaching an online course? Should faculty attend an online instructional design seminar or a mini-course?

The successful delivery of an online curriculum goes beyond knowledge of a specific Learning Management System. Learning Management Systems synthesize many academic technologies and sources of academic content. Is a PowerPoint presentation provided by a publisher an effective substitute for an instructor-developed presentation based on the content of their normal on-ground class lecture? Capturing and delivering on-ground content should involve more than recording the on-ground lecture. Other online tools, sources and assessments are available to create a rich experience for the online student 


\section{Issues in Information Systems}

Volume 13, Issue 2, pp. 41-50, 2012

The effect of academic discipline on the use of online course tools is less clear. Some faculty and disciplines may have assumed that their content, assessment, and requirements for quality control are not appropriate for online delivery. While some of these concerns may be valid, faculty in some disciplines may not be prepared to use basic academic technologies required to effectively deliver this online content or worse yet be biased against online course delivery.

Faculty background in educational technology, i.e. word processing, PowerPoint, image, audio and video technologies, may be as important as teaching faculty to use a learning management system. Faculty background in education technologies may also be important across a variety of academic disciplines and content areas.

\section{REFERENCES}

1. Agresti, Alan. 1996. An Introduction to Categorical Data Analysis. John Wiley and Sons, Inc.

2. Bacow, L., Bowen, W. and Guthrie, K. (2012) Barriers to Adoption of Online Learning Systems in U.S. Higher Education. Retrieved on 5/3/2012 from http://www.sr.ithaka.org/research-publications/barriers-adoptiononline-learning-systems-us-higher-education

3. Brooks, D. (2012). The Campus Tsunami. New York Times. Retrieved on 5/10/210 from http://www.nytimes.com/2012/05/04/opinion/brooks-the-campus-tsunami.html? r=1

4. Guidry, K., Lorenz, A. (2010). A Comparison of Student and Faculty Academic Technology Use Across Disciplines, Educause Quarterly Magazine, Volume 33, Number 3 Retrived on 3/12/2011 from: http://www.educause.edu/EDUCAUSE\%2BQuarterly/EDUCAUSEQuarterlyMagazineVolum/AComparisonofSt udentandFaculty/213682

5. Fry, J. (2012). "As Elite Universities Embrace Online Learning" Letter to The New York Times. Retrieved on 5/10/2012 from http://www.nytimes.com/2012/05/09/opinion/as-elite-universities-embrace-online-learning.html

6. Introduction to R. Retrieved on 2/15/2012 from http://www.r-project.org/

7. Laverty, J., Wood, D, Tannehill, D, Kohun, F. and Turchek, J. (2012). Improving the LMS Selection Process: Instructor Concerns, Usage and Perceived Value of Online Course Delivery Tools. Information Systems Education Journal. Volume 10. Pages 71-88.

8. Lewin, T. (2012). "Harvard and M.I.T. Team Up to Offer Free Online Courses" New York Times. Retrieved on 5/10/2012 from http://www.nytimes.com/2012/05/03/education/harvard-and-mit-team-up-to-offer-free-onlinecourses.html? $r=1$ 